\title{
Changing Views on Motivation in a Globalizing World
}

\section{Elizabeth Wadell}

\section{Diablo Valley College, California}

\section{April Shandor}

\section{English Center, Oakland, California}

Given that English is an international language that belongs to every[one] in the world, I think the motivation related to English learning should be understood in the context of an international point of view. -MA TESOL graduate student

I learned that there are different types of motivation. ...I also learned that there is a definition to describe my desire to be part of the international community: International Posture. -MA TESOL graduate student

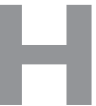
ow is globalization changing our understanding of students' motivation to learn English as a Foreign Language (EFL)? As the quotes above illustrate, it affects how we understand our students as well as our own positions as teachers in an international world. Although several authors have put forward teaching suggestions based on today's international perspective (e.g. Cates, 2004; Tanaka \& Fukada, 2007), no known studies have attempted to address the issue through the lens of pre-service EFL and ESL teachers. Many experienced teachers in the EFL field are familiar with approaches that consider the role of globalization, but how are new teachers incorporating these theories into their teaching? In this article, we will use the voices and experiences of novice teachers to examine how a more global perspective on English is changing the way we understand motivation. We will then present some ideas for applying this view to language teaching practices. We share our ideas in the hope that other teachers will join us in considering how theories of motivation can be applied in both EFL and TEFL/TESOL classrooms across the globalizing world.
Traditionally, language learning motivation was conceived as being either "instrumental" or "integrative," but recent research suggests that in today's globalizing world this distinction no longer holds for many learners of English. Over the past ten years, there has been a shift away from the view of English learning as a way to integrate into American/British/Australian culture. Many scholars are now exploring the ways in which EFL learners develop international identities while simultaneously retaining their own cultures. The authors of the current article-English language teachers and graduate students - discuss how their research on new concepts in motivation led them to engage with their colleagues on the issue, and ultimately, to change their own teaching.

伝統的に、言語学習の動機づけには 道具的動機づけと統合的動機づけが あると考えられてきたが、最近の研 究では今日のグローバル社会におい て、多くの英語学習者には、この区別 はないと言われている。この10年で、 「英語学習はアメリカ、イギリス、オ 一ストラリア等の文化への統合方法 である」という従来の見方は変化し てきた。現在、多くの研究者は、英語 学習者が、いかに自分自身の文化を 保持しつつ国際的アイデンティティ を発展させるかを研究している。本 論では、英語教師で大学院生でもあ る研究者たちが、独自の研究により 動機づけの新概念に関する問題を提 示し、どのように自身の英語教授法 を変えたのかを論じる。 


\section{What is Motivation?}

During our early experiences as native English speakers teaching in ESL and EFL contexts, both authors had a common sense understanding that motivation is important for language learning; however, it was not until we enrolled in a course in Second Language Acquisition (SLA) at the American university where we were studying for our MA TESOL (Teaching English to Speakers of Other Languages) degrees that we contemplated exactly what it means to be motivated to learn a second language. As a class requirement, we both enrolled in a Japanese class and reflected on our own learning. Neither of us were very successful Japanese learners. Why? We saw lack of motivation as the main cause. Like many EFL learners who have never visited English-speaking countries or interacted with native speakers of the language, we did not need to learn Japanese to communicate with native speakers. Lacking this push, we felt no real reason to learn Japanese. This, we assumed, is the role of motivation in second language learning.

This explanation of our learning was based in the traditional socio-educational model of language learning motivation, the dominant theory since the 1950s. This model suggests that learners who desire to "integrate" into the target language culture will be more successful because of their higher overall motivation to learn the language and greater frequency of communication in the target language (Gardner, Lalonde, \& Pierson, 1983). The theory also identifies instrumental orientation, the desire to acquire a language for work or as an academic requirement. Viewed through the socio-educational model, our instrumental reasons for taking the class were not strong enough to take us past the single obligatory semester, and therefore, our language development came to a close.

However, while the socio-educational modelfirst proposed in Canada in the 1950s—described our own foreign language learning, it is not the only way to look at motivation. Newer theories take into account factors influencing EFL learners that move beyond simply integrative and instrumental orientations. As graduate teaching assistants in an introductory SLA class for incoming MA TESOL students, we hoped to introduce these current and future teachers to motivation research which considers the role of global English and the diverse contexts of today's English language learners.

The theories we introduced to them are based in an understanding of how learners' identities
- how they are socially situated as well as how they choose to position themselves - influence their language learning opportunities (Norton Peirce, 1995; Menard-Warwick, 2005). For many EFL learners, that identity is tied to their position in a globalizing economy. In a study of Indonesian middle school students, Lamb (2004) found that aspects of instrumental and integrative motivation were combined in the learners' developing "bicultural identities." While the learners saw themselves as connected to a global, English-speaking culture, they simultaneously maintained the aspects of the identity in which they were firmly rooted, local Indonesian culture. Another way to look at this globalizing identity is through Dörnyei's (2005) concept of the "L2 Motivational Self System," which integrates theories of motivation with a psychological approach toward identity, considering learners' "ideal selves," or idealized self-representations, as an integral part of their language learning experiences. Interested in the self-representations of Japanese high school students, Yashima (2009) found that many learners had "international posture;" i.e., they envisioned themselves as future members of an international community and saw English as the tool for gaining access to that community.

\section{New Perspectives}

Theoretical constructs of motivation and identity developed in the context of globalization offer us an alternative to an English language classroom, which focuses on American or British culture and expressions. Given the significance of "bicultural identity" and "international posture" for many EFL students' learning, we wondered how graduate MA TESOL students/ pre-service teachers would understand these theories as applying to their own L2 learning and EFL/ESL teaching. After introducing them to the concepts through readings and class discussion, we asked them to share their ideas with us. We found that these theories resonated with many students and caused them to consider the roles of context and identity in language learning motivation. As one student, who had previously taught in Asia, told us:

\section{I feel like the motivation to access some kind of amorphous, globalized identity is definitely pre- sent in many of my students as well as the strong instrumental motivation to use English in their future careers.}

Another international student also referred to the complexity of motivation in learning English: 
I really agree that there should be a different way of exploring motivations of those who are situated in different contexts... I think the motivation related to English learning should be understood in the context of an international point of view.

This "international point of view" and consideration of motivational differences in "different contexts" was particularly salient in conversations with our international colleagues, many of whom planned to return to their native countries after graduation. Considering her own diverse English learning contexts, an international student from Asia explained that, as a child she associated English with North America, Great Britain, and Australia, but that even more it was a tool for exploring the outside world. Her experience perfectly describes Yashima's concept of "international posture," the desire to integrate not into a single target culture, but into the whole global society that uses English and other languages as mediums for communication.

In addition, other international classmates considered how a focus on integrative motivation can lead to bias against non-native English speaking teachers. In the words of one:

Teachers now know that students are associating English with more than just English speaking countries. Teachers can see the importance of bringing in models of speakers that are non-native speakers.

This dialogue enabled the graduate students to re-examine their own language learning experiences within the context of International Posture and Bicultural Identity. While some truly had experienced integrative motivation, others recognized how they had learned English (or another language) as a way of participating in a global community.

\section{Applying Theory to Practice}

When we asked the MA TESOL students for their ideas of how to apply new theories of motivation to the classroom, we got one answer: through culture. While culture has traditionally been brought into the foreign language classroom as a way of encouraging an integrative orientation (for example, through television shows or units on American holidays), our colleagues offered alternative views of culture, either as a way of looking outward to encourage international posture or of turning inward to examine their own culture-one facet of bicultural identity. For example, teachers could encourage international posture by introducing their students to a wide range of cultures. According to one graduate student:

Understanding the concept of international posture and multilingual/cultural identity is important for language instructors because increasingly, the focus of language learners is access to the international community more than one specific "foreign" culture. Language learning should be directed towards students who might be motivated by participation on an international level, and who need access to another language in order to successfully share information about their own culture, not gain access to another.

Thus, the teacher's role is to foster a global outlook - of which multilingualism is one part rather than to help learners understand a single target culture.

In an online discussion, the graduate students dove more deeply into what this could mean for teaching, and several focused on the role of materials from different cultures. One student from the United States asked how using non-Western materials and cultural items might influence students' motivation as well as "their perception of the English language itself." Her question was answered by an experienced teacher from Asia who used her own experiences as a learner to challenge the notion that English "belongs" to native English speakers. She pointed out that the very fact that she could discuss things like the typical Taiwanese food "taro soft buns" shows that English is evolving outside of the inner circle English-speaking countries, concluding that, "under the effects of globalization, English will never be the same."

In this picture, the whole integrative approach to culture is turned inside out. Rather than learning about a different culture as a way of acquiring both language and culture, EFL students may be more motivated by looking at their own culture from the global perspective. They can then understand that language is not something apart from their own culture and selves-it is, in some sense, a way of expressing who they already are, culturally speaking, and who they are in the process of becoming. Typically learners are seen as "adapting" to the new language and culture, but this student suggests that the English language itself has already adapted to these global learners.

From listening to our classmates' ideas, we realized that English teachers can also use culture to address bicultural identity, the sense that for some learners an international identity 
exists side-by-side with a strong local identity. This seemed to particularly strike a chord for experienced EFL teachers. A Korean middle and high school English teacher reported that:

With the understanding of motivation in the context of a globalizing world, language instructors can modify their teaching materials related to cultures. We used to take for granted that learning about culture is to learn about the culture of English speaking countries. But since students' interest is more in both keeping their national identities and global identities rather than integrating themselves into the target culture, the teaching materials should include their own culture written in English, various cultures beyond English speaking cultures and also global contexts such as how each country cooperates with one another in dealing with common business.

For this teacher, we see that culture is intertwined, not just with language, but also with identity. She suggests that learning about culture should be in the context of learners' own identities - a long way from the socio-educational model's focus on learning about and adopting a new culture!

\section{Looking Ahead}

Our colleagues' words illustrate the opinion that through culture, whether that of the target language, global cultures, or by understanding learners' own cultures, teachers can create or develop motivation in the classroom. We should be conscious of the ways our existing teaching practices may promote or inhibit the growth of language learning motivation and move forward with those practices which best suit our students. Through a focus on practices that support the expression of culture and identity, we can give them a place to develop their international postures and bicultural identity.

The following suggestions for the EFL classroom context are based on the understanding of motivation in a globalizing world that developed as a result of our exploration with the graduate students in the TESOL program:

1. Emphasize a plurality of cultures rather than a homogenous culture. Incorporate teaching materials that enable students to explore their own cultures in relation to many others, thereby preparing them to actively participate in a larger international community outside of the classroom. Also, consider ways in which classrooms themselves are international communities - even in monolingual classes students may have different ethnicities or experiences abroad.

2. Assess students' "international postures" and focus on global issues and international connections according to students' interests. Additionally, facilitate students' access to particular sub-cultures, such as the international business community.

3. Discuss with pre-service and novice ESL teachers how students may have internationally-oriented motivation and how to put these theories into practice in the classroom.

We offer these suggestions in light of current theories on motivation and identity in a globalizing world. Although these views are familiar to many teachers who stay current in the field, our experience points out that they are not intuitive to many new or pre-service teachers. We should continue striving to find ways to put these theories into practice in the classroom and assist new teachers in recognizing and facilitating learner motivation in a globalizing world.

\section{References}

Cates, K. (2004). Becoming a global teacher: Ten steps to an international classroom. The Language Teacher, 28 (7), 31-36.

Dörnyei, Z. (2005). The psychology of the language learner: Individual differences in second language acquisition. Mahwah, New Jersey: Lawrence Erlbaum Associates. Gardner, R., Lalonde, R., \& Pierson, R.

Dornyei, Z. (1983). The socio-educational model of second language acquisition: An investigation using lisrel causal modeling. Journal of Language and Social Psychology 2 (1), 1-15.

Lamb, M. (2004). Integrative motivation in a globalizing world. System (32), 3-19.

Menard-Warwick, J. (2005). Both a fiction and an existential fact: Theorizing identity in second language acquisition and literacy studies. Linguistics and Education 16, 253-274.

Norton, B. (2000). Identity and language learning: Gender, ethnicity and educational change. Harlow, England: Pearson Education Limited.

Norton Pierce, B. (1995). Social identity, investment, and language learning. TESOL Quarterly (29)1, 9-31.

Tanaka, H., \& Fukada, Y. (2007). Comprehensive needs analysis for NGO staff. In K. Bradford-Watts (Ed.), JALT2006 Conference Proceedings (396-406). Tokyo: JALT. 
Yashima, T. (2009). International posture and the ideal L2 self in the Japanese EFL context. In Z. Dörnyei \& E. Ushioda (Eds.) Motivation, language identity and the L2 self (144-163).

Bristol, UK: Multilingual Matters.

Elizabeth Wadell teaches at the International Education Center at Diablo Valley College in Pleasant Hill, California. She received her MA TESOL from San Francisco State University and is interested in learner identity and L2 academic writing.

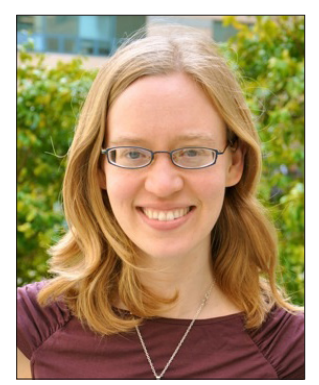

April Shandor received her master's degree in linguistics from San Francisco State University. She teaches at the English Center in Oakland, California. Her current research interest is on the ways in which patterns of classroom discourse can positively influence learners'

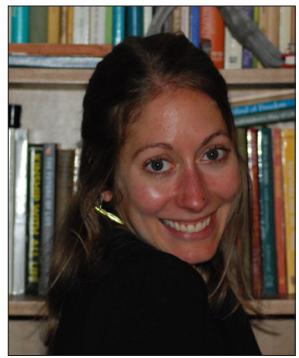
lives outside of the classroom.
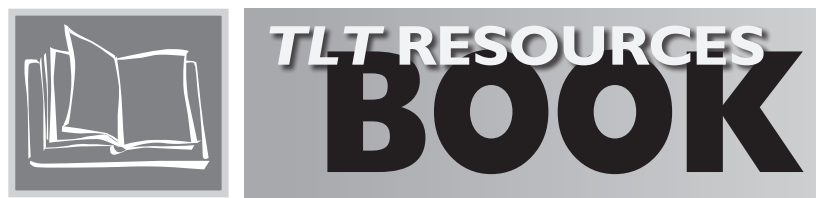

\section{...with Robert Taferner}

To contact the editor: <reviews@jalt-publications.org>

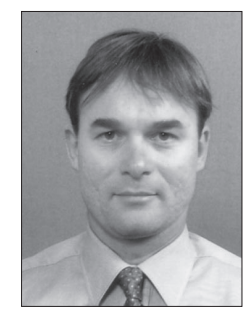

If you are interested in writing a book review, please consult the list of materials available for review in the Recently Received column, or consider suggesting an alternative book that would be helpful to our membership.

BOOK REVIEWS ONLINE: A linked index of Book Reviews can be found at:

$<$ jalt-publications.org/tt/departments/book-reviews $>$

This month's column features Arthur Lauritsen's evaluation of English Explorer 1.

\section{English Explorer I}

[Helen Stephenson. Heinle Cengage Learning, 201 I. p. I28. $¥ 2,4$ I 5. ISBN: 978-0-4959086|-6.]

Reviewed by Arthur Lauritsen, Momoyama University

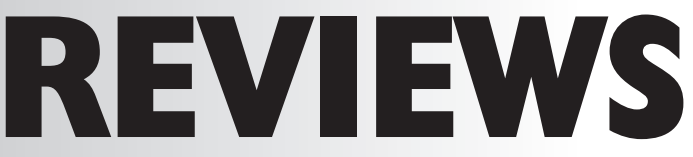

English Explorer 1 provides a complete 4-skills lesson package with a focus on global understanding. The first book in the series is geared towards lower level high school and university aged students. The complete series runs up to level 4. Each book in the series comes with a workbook, CD-ROM, and teacher's book, each of which is illustrated with bold travel pictures and cultural stories, the hallmarks of National Geographic.

The English Explorer 1 student book is divided into eight units, and each of these units is further divided into two-page lessons. A lesson will start off with a dialog listening section followed by simple vocabulary, grammar, and speaking exercises. The workbook in this series is a homework-centered collection of vocabulary

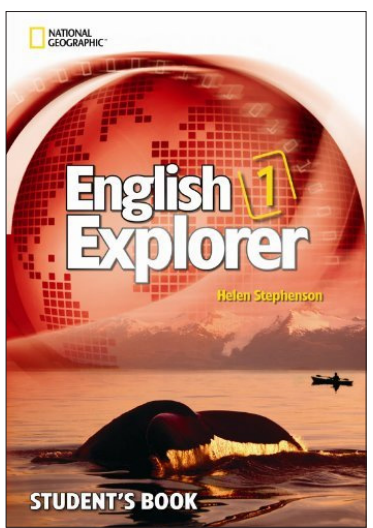
and grammar exercises and reading tasks based on a cultural topic. The teacher's book includes: a cheat sheet, a collection of transcripts, lesson plans, and pre-made unit tests. Included in the package is Interactive Whiteboard Software, a software program that allows for clear presentation of the material for classrooms set up with the proper CALL equip- 